Anais da Academia Brasileira de Ciências (2013) 85(3): 1047-1052

(Annals of the Brazilian Academy of Sciences)

Printed version ISSN 0001-3765 / Online version ISSN 1678-2690

www.scielo.br/aabc

\title{
Daily and seasonal activity patterns of free range South-American rattlesnake (Crotalus durissus)
}

\author{
ALEXANDRO M. TOZETTI ${ }^{1}$ and MARCIO MARTINS ${ }^{2}$ \\ ${ }^{1}$ Laboratório de Ecologia de Vertebrados Terrestres, Universidade do Vale do Rio dos Sinos/ UNISINOS, \\ Avenida Unisinos, 950, 93022-000 São Leopoldo, RS, Brasil \\ ${ }^{2}$ Departamento de Ecologia, Instituto de Biociências, Universidade de São Paulo, \\ Caixa Postal 11461, 05422-970 São Paulo, SP, Brasil
}

Manuscript received on June 13, 2011; accepted for publication on September 4, 2012

\begin{abstract}
This study aimed at describing daily and seasonal variation in the activity of a population of SouthAmerican rattlesnakes (Crotalus durissus) in a savanna like habitat (Cerrado) in Southeastern Brazil. Seasonal and daily activities of snakes were evaluated by the number of captures of snakes during road surveys, accidental encounters, and relocations by radio-tracking. Our results show that climatic variables such as air temperature and rainfall have little influence on the activity pattern of rattlesnakes. Our findings indicate that rattlesnakes spend most of the day resting and most of the night in ambush posture. The South-American rattlesnake is active throughout the year with a discrete peak in activity of males during the matting season. The possibility of maintaining activity levels even during the coldest and driest season can facilitate the colonization of several habitats in South America. This possibility currently facilitates the colonization of deforested areas by rattlesnakes.
\end{abstract}

Key words: Cerrado, ethology, squamata, radio-track.

\section{INTRODUCTION}

Although the concept of activity is very broad, herpetological studies frequently associate activity with movement patterns of snakes, and consequently to their capture rates (Gibbons and Semlitsch 1987, Oliveira et al. 2013). These movements might be associated with migration, dispersion of newborns, escape from predators, search for shelters for daily thermoregulation, food, or mates for reproduction (Gibbons and Semlitsch 1987). As a result of its association with movements, activity may vary depending on gender, age, reproductive condition,

Correspondence to: Alexandro Marques Tozetti

E-mail: alexandro.tozetti@gmail.com or molting (Duvall et al. 1985, Macartney et al. 1988). Unlike in temperate areas, in most tropical regions, the winter, even the most harsh, does not seem to prevent the activity of most ectotherms, which tend to remain active throughout the year (Marques et al. 2000, Tozetti et al. 2010).

In in tropical areas of South America, snake assemblages have shown activity peaks during the warmer, rainy season (mid-spring to early autumn; Marques et al. 2000, Maciel et al. 2003). The rattlesnake Crotalus durissus, however, exhibits a peak of activity in the dry/colder season (autumn) (Salomão et al. 1995). The peak activity of rattlesnakes in the coldest season of the year may 
seem unexpected, especially when considering that the activity of ectotherms is directly dependent on the thermal regime of the environment (Huey et al. 1989). However this pattern may reflect the fact that during this season males search for females to mate (April to June) (Salomão and AlmeidaSantos 2002). Activity can also be subdivided into specific activities, such as foraging, reproduction or thermoregulation. The difficulty of examining all behaviors that compose the activity of snakes might be the reason why most studies have presented activity from a general point of view, based on encounter rates of snakes found during visual surveys, captured in traps or based on records of specimens in collections (Salomão et al. 1995, Dorcas and Willson 2009). However, the importance of each one of these factors on snake activity remains poorly understood and data from field studies on South American rattlesnakes are extremely rare in the literature. Here we describe the daily and seasonal activity patterns of $C$. durissus based on the encounter rate and radio tracking of a population of this species inhabiting an open Cerrado remnant, a savanna like habitat in Southeastern Brazil.

\section{MATERIALS AND METHODS}

Field work was conducted at the Itirapina Ecological Station (IES: 2.300 ha; 22 ${ }^{\circ} 13^{\prime 2} 24^{\prime \prime}$ S; $47^{\circ} 54^{\prime} 03^{\prime \prime} \mathrm{W} ; 700 \mathrm{~m}$ of elevation), municipality of Itirapina, State of São Paulo, Southeastern Brazil. Regular sampling was conducted from December 2003 to December 2004. The main vegetation types in the reserve are grasslands and shrubby grasslands. The climate is mesothermic, with two well-defined seasons, a dry/cold between April and August (average monthly rainfall from 18-42 $\mathrm{mm}$ ) and a wet/warm season between September and March (88-368 $\mathrm{mm})$. During the dry/cold season in the study period, the minimum air temperatures ranged from 0 to $5^{\circ} \mathrm{C}$ and maximum from 31 to $35^{\circ} \mathrm{C}$. At the same period in the rainy/ warm season the air temperature variations were 7 to $15^{\circ} \mathrm{C}$ and 36 to $39^{\circ} \mathrm{C}$ respectively.

Snake's activity was evaluated by: (1) captures during car surveys along unpaved roads and firebreaks that cut the study area, (2) accidental encounters, and (3) relocation of animals equipped with radio-transmitters. Field work consisted of regular sampling during five consecutive days, every 20 days. In each sampling period, unpaved roads and firebreaks at IES were run daily between 6 am and $24 \mathrm{pm}$, in a systematic manner with a vehicle at a speed below $35 \mathrm{~km} / \mathrm{h}$. Captured animals were weighed, measured, and implanted with a passive integrated transponder. Snakes were also examined by abdominal palpation in order to detect gravid females. Animals with body mass above $250 \mathrm{~g}$ were equipped with radio-transmitters (model SI-2; $9 \mathrm{~g}$, $33 \mathrm{~mm}$ x $11 \mathrm{~mm}$; Holohil Systems Ltd., Ontario, Canada) externally attached with adhesive tape. The device never accounted for more than $5 \%$ of the animal's body mass. The transmitter was externally attached to the dorsal region, at the posterior third of the snake's body using duct tape. The detachment of transmitters occurred during shedding. Animals were observed moving through dense vegetation, basking, foraging, and even capturing and ingesting a prey offered by us. This suggests that the apparatus generate a low level of interference on snake's behavior(Tozetti and Martins 2007,2008). Sequential relocations of a radio-tagged individual snake were conducted with an interval of minimum 12 hours. Radio-tracking provided visual contact with almost all snakes that were relocated both by day and at night to maximize the observation of different behaviors. In each snake re-location, air temperature, relative humidity, and substrate temperature were recorded. Climate data were obtained from a meteorological station near the study area. We have estimates both, seasonal and diel snake's activity. Seasonal activity was assessed exclusively based on the numbers of captured snakes during car surveys. We considered snake capture rates as an indicator of snake activity. 
Capture rates were estimated by dividing the total number of captures by the sampling effort of each month (e. g., in January the sampling effort was $53.7 \mathrm{~km} /$ day and we captured two snakes; thus, the capture rate was $2 / 53.7=0.037$ snakes $/ \mathrm{km} /$ day).

Diel activity was assessed using the records of capture of snakes by car surveys, accidental encounters, and relocations from radio-tracking. Diel activity was classified as: coiled alert, coiled hunting, moving, coiled resting, and basking. Each observation (capture or re-location) was considered as a record. Records of animals that were disturbed when they were found were not considered. The activity of non-moving animals was determined based on the method proposed by Oliveira and Martins (2001), as follow: (a) coiled hunting when the body was coiled, the neck was forming an S-coil and the head was lying over the body coils forming an angle $>20$ o in relation to the ground; (b) coiled alert when the body was coiled, the neck was forming an S-coil and the head was lying over the body coils forming and angle $<20$ o in relation to the ground; (c) basking when the snake was found during daytime with the body extended or partially extended; and (d) coiled resting when the body was loosely coiled, the neck was held straight and the head formed an angle $<20^{\circ}$ in relation to the ground.

Considering the null hypothesis that rattlesnakes have the same probability of being observed performing each of the five types of activity, the expected number of monthly records for each activity was defined as one fifth of the total number of observations in each month. We classified as daytime activities all records from 6:00 am to $5: 59 \mathrm{pm}$ and nighttime as those made between 6:00 to $12: 00 \mathrm{pm}$. We used a Mann-Whitney $U$-test to test for differences in activity between sexes and seasons. The relationships between activity and environmental variables were compared using Spearman Rank Correlation tests $\left(r_{s}\right)$. In all cases, differences were considered significant when $P<$ 0.05 (Zar 1999).

\section{RESULTS}

During the study, 38 rattlesnakes were captured (16 = car surveys; 22 = accidental encounters). Twelve were females (mean body size $=896.2 \mathrm{~mm}$; range $=537-1,335 \mathrm{~mm}$ ) and twenty-six were males (mean body size $=977.7 \mathrm{~mm}$; range $=637-1256 \mathrm{~mm})$. A total of $12,000.36 \mathrm{~km}$ were covered with a vehicle in 224 sampling days. Throughout the study, the capture rate of rattlesnakes based exclusively on the captures obtained with the road survey $(n=16)$ was 0.30 snakes $/ \mathrm{km} /$ day. Capture rates significantly increased as air humidity increased $\left(r_{s}=0.58 ; P\right.$ $<0.05 ; n=12)$. On the other hand, no significant correlation was found between capture rate and daily maximum air temperatures $\left(r_{s}=0.45 ; P=\right.$ $0.14 ; n=12)$, minimum air temperatures $\left(r_{s}=0.51\right.$; $P=0.09 ; n=12)$ or rainfall $\left(r_{s}=0.30 ; P=0.32 ; \mathrm{n}\right.$ $=12$ ). Capture rates were not significantly different when the dry and rainy seasons were compared (0.9 and 0.20 snakes $/ \mathrm{km} /$ day, respectively; $U=17 ; P$ $=0.93 ; n=12)$. Capture rates were not different between sexes $(0.17$ snakes $/ \mathrm{km} /$ day for males and 0.13 snakes $/ \mathrm{km} /$ day for females; $U=63 ; P=0.58$; $n=24)$. Capture rates of females were not different between the rainy and dry seasons $(0.11$ snakes $/ \mathrm{km} /$ day and 0.02 snakes $/ \mathrm{km} /$ day, respectively; $U=10$; $P=0.22 ; n=12$; Figure 1). Similarly, capture rates of males were not different between the rainy and dry seasons ( 0.09 snakes/km/day and 0.07 snakes/ $\mathrm{km} /$ day, respectively; $U=17 ; P=0.93 ; n=12$ ), despite a discrete peak in activity of males during the matting season (Figure 1).

Only 20 rattlesnakes (13 males and 7 females) were able to be equipped with radio-transmitters (exhibit minimal body mass). Snakes were radiotracked during a mean of 64.9 days ( 9.5 relocations). During the day, resting was observed in a higher frequency than expected $\left(46.1 \%\right.$ of samples; $\chi^{2}=$ 30.3; $G L=10 ; P<0.001$; Table I). The number of observations of the remaining activities was not significantly different from expected (alert: $\chi^{2}$ 


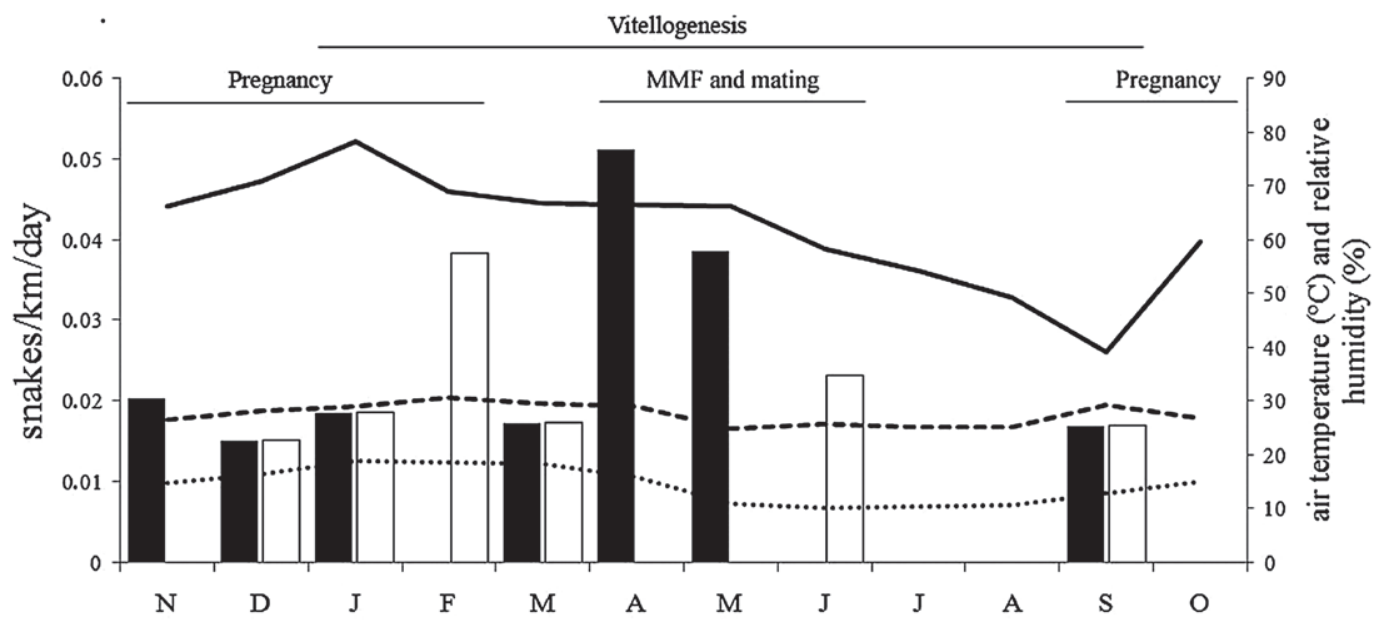

Figure 1 - Seasonal activity (snakes/km/day) of Crotalus durissus based on captures during the road survey in Southeastern Brazil.

Black columns = males; white columns = females; solid line = mean of relative air humidity; dashed lines = maximum and minimum air temperatures; $\mathrm{MMF}=$ male-male fighting. Reproductive data obtained from: Salomão et al. (1995), Salomão and Almeida-Santos (2002), Almeida-Santos et al. (2004).

TABLE I

Number of records for each activity performed by rattlesnakes (Crotalus durissus) at the moment they were found during road surveys, accidental encounters, and radio-telemetry at the IES. The percentage of a given activity in a given period of the day is shown between parentheses.

\begin{tabular}{ccc}
\hline Activity & Day & Night \\
\hline Coiled alert & $16(15.4 \%)$ & $17(23.3 \%)$ \\
Coiled hunting & $10(9.6 \%)$ & $35(47.9 \%)$ \\
Moving & $6(5.8 \%)$ & $9(12.3 \%)$ \\
Coiled resting & $48(46.1 \%)^{*}$ & $12(16.4 \%)$ \\
Basking & $24(23.1 \%)$ & - \\
Totals & $\mathbf{1 0 4 ( 1 0 0 \% )}$ & $\mathbf{7 3 ( 1 0 0 \% )}$ \\
\hline
\end{tabular}

$*=$ observed value significantly higher than expected.

$=4.4 ; G L=8 ; P=0.82$; hunting: $\chi^{2}=3.35 ; G L$ = 5; $P=0.65$; movement: $\chi 2=1.2 ; G L=2 ; P=$ 0.56; basking: $\chi^{2}=8.5 ; G L=8 ; P=0.38$; Table I). At night, the activities observed did not vary significantly in relation to expected values (alert: $\chi^{2}$ = 1.97; $G L=7 ; P=0.96$; hunting: $\chi^{2}=23.25 ; G L$ =18; $P=0.18$; movement: $\chi^{2}=1.87 ; G L=6 ; P=$ 0.93; resting: $\chi^{2}=3.07 ; G L=15 ; P=0.99$; Table I).

\section{DISCUSSION}

Our data show that $C$. durissus remains active throughout the year with a discrete peak in activity of males during the matting season. This may reflect the fact that during this season males search for females to mate (April to June; Salomão and Almeida-Santos 2002). This variation may not be significant due to the small number of males captured. For females, the lack of changes in the activity between seasons may be due by their sedentary lifestyle, as observed for females of Bothrops jararaca (Sazima 1988) and B. atrox (Oliveira and Martins 2001). No females with embryos were captured, supporting the hypothesis that gravid females are less mobile (Gibbons and 
Semlitsch 1987). Also, gravid females represent a small part of the female population due to the biannual reproductive cycle of rattlesnakes (Almeida-Santos and Salomão 1997, AlmeidaSantos et al. 2004).

Previous data of activity of $C$. durissus was obtained from preserved specimens in herpetological collections and reveal that most of the seasonal variation in rattlesnakes activity is due to dispersal of juveniles (Salomão et al. 1995). On the other hand, our findings indicate that adult rattlesnakes have a constant activity pattern throughout the year, with slight drops during colder months. Moreover, changes in activity could be detected in future studies that investigate intraday variation of the activity. During the colder months, for example, individuals of $C$. atrox, C. cerastes, C. molossus and $C$. tigris were more active at midday while in the cooler were predominantly nocturnal or crepuscular (Secor 1994, Beck 1995). We hypothesized that this might be a pattern for the genus (Tozetti et al. 2009).

Concerning dial activity, resting is the predominant activity during the day and movements are not very frequent, as also observed for Bothrops jararaca, B. atrox and other species of Crotalus (Duvall et al. 1985, Sazima 1988, Beck 1995, Oliveira and Martins 2001). Movements probably increase the risk of predation and exposure to adverse environmental conditions (Gibbons and Semlitsch 1987, Bonnet et al. 1999), which may be avoided during the day. From this point of view, the selection of a foraging site that could also provide the diurnal thermoregulatory requirements is essential, reducing the need of moving. Despite the importance of basking to control the metabolic activity of ectotherms (Huey et al. 1989), the number of records of animals performing this activity was relatively low. Perhaps the vegetation structure, associated with the relatively warm winter, keep the average daily temperatures from oscillating much among seasons, decreasing the need of prominent changes in activity associated with thermoregulatory needs. Hunting was typically a nocturnal activity, the period that coincides with the peak of prey activity (rodents; see Emmons and Feer 1997). In addition, the selection of hunting sites is not random, but rather based on chemical cues from prey, maximizing the probability of finding them even during the day (Reinert et al. 1984).

Our findings support some of the hypothesis on the daily and seasonal activities of South American rattlesnakes previously described in studies on specimens from collections, on captive animals, or from opportunistic sightings in the field. Compared to the North-American rattlesnakes, $C$. durissus is active throughout the year what may be allowed both by favorable weather conditions. These features clearly facilitated the colonization by $C$. durissus of several open habitats in South America during its spread in the continent (Wüster et al. 2005), as well as facilitated its invasion of deforested areas throughout its distribution (e. g., Bastos et al. 2005).

\section{ACKNOWLEDGMENTS}

This study was developed with field assistance of several people, especially Victor Vetorazzo. We also thank Denise Zancheta (Inst. Florestal - SP) for permissions, Fundação de Amparo à Pesquisa do Estado de São Paulo (FAPESP) and Conselho Nacional de Desenvolvimento Científico e Tecnológico (CNPq) for the grants received.

\section{RESUMO}

O estudo teve como objetivo descrever as variações na atividade sazonal e diária de uma população de cascavéis (Crotalus durissus) no Cerrado do sudeste brasileiro. As atividades sazonais e diárias das cobras foram avaliadas por meio de capturas em amostragens em rodovias, encontros ocasionais e rádio rastreamento. Nossos resultados indicam que variáveis ambientais como a temperatura do ar e a pluviosidade têm pouca influencia na atividade das cascavéis. Nossos dados indicam que elas passam a maior parte do dia em repouso e a maior parte da noite 
forrageando. A cascavel da América do Sul se mostra ativa o ano todo com um pico moderado na atividade de machos durante a estação reprodutiva. A possibilidade de manter níveis de atividade até mesmo durante a estação mais fria e seca do ano pode facilitar a colonização de vários habitats na América do Sul favorecendo a colonização de cascavéis em áreas desflorestadas.

Palavras-chave: Cerrado, etologia, squamata, radiotelemetria.

\section{REFERENCES}

ALMEIDA-SANTOS SM, ABDALla FP, SiLVEIRA PF, YAMANOUYE N AND SALOMÃo MG. 2004. Reproductive cycle of the Neotropical Crotalus durissus terrificus (seasonal levels and interplay between steroid hormones and vasotocinase). Gen Comp Endocrinol 139: 143-150.

AlmEIDA-SANTOS SM AND SALOMÃo MG. 1997. Long-term sperm storage in the female neotropical rattlesnake Crotalus durissus terrificus (Viperidae, Crotalinae). Japanese Journal Herpetology 17: 46-52.

BAstos EGM, ARAúJO AFB AND SILVA HR. 2005. Records of the rattlesnakes Crotalus durissus terrificus (Laurenti) (Serpentes, Viperidae) in the State of Rio de Janeiro, Brazil: a possible case of invasion facilitated by deforestation. Rev Bras Zoo 22: 812-815.

BECK D. 1995. Ecology and the energetics of tree sympatric rattlesnake species in the Sonoran Desert. J Herpetol 29: 211-223.

BonNet X, NAUlleau G AND Shine R. 1999. The dangers of leaving home: dispersal and mortality in snakes. Biol Conserv 89: 39-50.

DORCAS ME AND WILLSON JD. 2009. Innovative methods for studies of snake ecology and conservation. In: MULLIN S AND SEIGEL R (Eds), Snakes: Applied Ecology and Conservation, Ithaca: Cornell University Press, New York, USA, p. 5-37.

DUVALL D, KING MB AND GUTZWILLER KJ. 1985. Behavioral ecology and ethology of prairie rattlesnake. Natl Geogr Res 1: 80-111.

EMMONS LH AND FEER F. 1997. Neotropical rainforest mammals: a field guide. The University of Chicago Press: Chicago, $307 \mathrm{p}$.

GIBBONS JW AND SEMLITSCH RD. 1987. Activity patterns. In: SEIGEL RA ET AL. (Eds), Snakes: Ecology and Evolutionary Biology, New York: McMillan Publishing Company, New York, USA, p. 396-421.

Huey RB, Peterson CR, ARnold SJ AND Porter W. 1989. Hot rocks and not-so-hot rocks: retreat site selection by garter snake and its thermal consequences. Ecology 70: 931-934.

Macartney JM, GREgORY PT AND LARSEN KW. 1988. A tabular survey of data on movements and home ranges of snakes. J Herpetol 22: 61-73.
MACIEL AP, DI-BERNARDO M, HARTZ SM, OLIVEIRA RB AND PONTES GMF. 2003. Seasonal and daily activity patterns of Liophis poecilogyrus (Serpentes: Colubridae) on the north coast of Rio Grande do Sul, Brazil. AmphibiaReptilia 24: 189-200.

MARQues OAV, ETEROVIC A AND ENDO W. 2000. Seasonal activity of snakes in the Atlantic forest in southwertern Brazil. Amphibia-Reptilia 22: 103-111.

Oliveira MCLM, SANTOS MB, LOEBMANN D, HaRTMAN A AND TOZETTI AM. 2013. Diversity and associations between coastal habitats and anurans in southernmost Brazil. An Acad Bras Cienc 85: 575-582.

OliveIRA ME AND MARTINS M. 2001. When and where to find a pitviper: activity patterns and habitat use of a lancehead Bothrops atrox, in central Amazonia, Brazil. Herpetol Nat Hist 8: 101-110.

ReINERT HK, Cundall D AND Bushar LM. 1984. Foraging behavior of the timber rattlesnake, Crotalus horridus Copeia 4: 976-981.

SAlomão MG AND Almeida-SAnToS SM. 2002. The reproductive cycle in male neotropical rattlesnake (Crotalus durissus terrificus). In: CAMPBELL JA AND BROODIE JR (Eds), Biology of the Pitvipers, Arlington: Univ. Texas, p. 506-514.

Salomão MG, Almeida-SAntos SM And Puorto G. 1995. Activity pattern of Crotalus durissus (Viperidae, Crotalinae) feeding, reproduction and snake bite. Etud Neotrop Fauna E 30: 101-106.

SAZIMA I. 1988. Um estudo de biologia comportamental da jararaca, Bothrops jararaca, com uso de marcas naturais. Memo Inst Butantan 50: 83-99.

SECOR SM. 1994. Ecological significance of movements and activity range for the side winder, Crotalus cerastes. Copeia 3: 631-645.

TOzETTI AM AND MARTINS M. 2007. A technique for external radio-transmitter attachment and the use of thread-bobbins for studying snake movements. South American Journal of Herpetology 2: 184-190.

TozetTi AM AND MARTINs M. 2008. Habitat use by the South American rattlesnake (Crotalus durissus) in southeastern Brazil. J Nat Hist 42: 1435-1444.

TOZETTI AM, PONTES GMF, MARTINS MB AND OLIVEIRA RB. 2010. Temperature preferences of Xenodon dorbignyi: field and experimental observations. Herpetol J 20: 277 280.

Tozetti AM, Vettorazzo V and Martins M. 2009. Shortterm movements of the South American rattlesnake (Crotalus durissus) in southeastern Brazil. Herpetol J 19: 201-206.

WÜSTER W, FERGUSON JE, QUIJADA-MASCAREÑAs JA, POOK CE, SAlOMÃo MG AND THORPE RS. 2005. Tracing an invasion: landbridges, refugia and the phylogeography of the neotropical rattlesnake (Serpentes: Viperidae: Crotalus durissus). Mol Ecol 14: 1095-1108.

ZAR JH. 1999. Biostatistical Analysis, $4^{\text {th }}$ Edition. Upper Saddle River: Prentice-Hall, Inc. 